\title{
Nï Jotï Aye: Jkyo Jkwainï/Libro Comunitario Jotï: Historia, Territorio, y Vida. By Eglée Zent, Stanford Zent, and Nï Joti y Jodena U. 2019. Ediciones IVIC (Instituto Venezolano de Investigaciones Científicas), Caracas. 530 pp.
}

\author{
Eugene N. Anderson ${ }^{1^{*}}$ \\ ${ }^{1}$ Department of Anthropology, University of California, Riverside, USA. \\ 'gene@ucr.edu
}

Received November 8, 2021

OPEN ひACCESS

Accepted November 8, 2021

Published January 29, 2022

DOI 10.14237/ebl.13.1.2022.1803

Copyright (c) 2022 by the author(s); licensee Society of Ethnobiology. This is an open-access article distributed under the terms of the Creative Commons Attribution-NonCommercial 4.0 International Public License (https://creativecommons.org/licenses/by-nc/4.0), which permits non-commercial use, distribution, and reproduction in any medium, provided the original author and source are credited.

This long and beautifully illustrated book is the culmination of decades of research by Eglée and Stanford Zent, a pair of Venezuelan researchers. Assiduous readers of ethnobiology will be familiar with the Jotï (or Hoti), thanks to many articles in Spanish or English by the Zents, often concerning mushroom use. The Joti are a tiny group, a bit over 1700 individuals, dwelling in the rainforest at the center of Venezuela. They are surrounded by larger, better-known groups, including the Piaroa and Yanomamo. Their language is distinctive and not clearly related to any other.

The book is an ethnographer's dream. It details every aspect of Joti life, especially use of and relationships with plants, fungi, and animals. Every detail is extensively documented with quotes and writings by Jotï people. The third author of the book is Ni Joti y Jodena U, a Jotï organization, which was created to map, document, and defend Joti lands, of course with considerable input from the Zents, who even taught the Joti to use GPS. The book is a collective project, which was planned and organized by this organization and other Joti. The detailed quotes make up most of the book, providing a record of Venezuelan Indigenous life approached before only by Johannes Wilbert's enormous collections of oral literature. This is what ethnography should bethorough documentation, as much of it in Native texts as possible. Franz Boas would be delighted to see it. At a time when ethnography is slipping badly in extent of documentation, this book stands out as an enormous beacon. I hope it converts many.

The Joti are typical Orinoco rainforest people, living by hunting, gathering, and preparing small conucos (shifting-cultivation fields) in which they grow maize, root crops, tree crops, and other foods and medicines. The fields are cropped with annuals for a year or so, then for the root crops as they grow up, then left as orchards, providing pockets of fruit trees in the forest. Hunting is largely by blowgun. Game seems to be abundant, even such large animals as tapirs that disappear once a forest gets opened and intruded. Over 100 species are hunted. Full lists of all plants and animals used are given in appendices.

The Joti worldview includes detailed origin stories with many animal transformations and contemporary mutual dependence between all living things. Animals have their Masters of the Game, such as Jkajwiyë Mowali, Chief of Peccaries, who resides in the sacred forest of Jelau (p. 464). These masters are often large or huge forms of the animal in question. Many plants, mountains, forests, waterways, and other features are sacred. Spirits of all sorts abound, both evil and good ones. Some people can transform themselves into animals, often for no good purpose. Festivals are numerous, often marking life passages. Coming of age is especially important and involves piercing the nasal septum. Festivals tend to involve consumption of local beer, but hallucinogens do not seem to have the same importance that they have in the Upper Amazon 
or among the Yanomamo. Purification after death is important.

Joti ideology includes a focus on the healthy, the good, and the beautiful, which recalls Plato's definition of philosophy as the study of the true, the good, and the beautiful. Unlike some neighbors, the Joti are peaceful and deeply committed to protecting their environment, since it is so much a part of their spiritual and religious world.

Change is coming, with more dangers than hopes. The usual threats, such as mining and military activity, have not been devastating so far but are coming closer. Introduced diseases, with malaria being the worst, are deadly, as is so often among Indigenous Americans. Health care is delivered through tiny rural clinics that have little ability to stop epidemics. The Zents are soliciting funds to fight malaria. Meanwhile, Venezuela's well-known descent into poverty and chaos is affecting the Joti less than might be expected since they are still self-sufficient and rather isolated in the forest environment. The Joti have organized, written up their rules and culture, and set boundaries on their territory, but their future in an increasingly desperate and poorly controlled nation is cloudy.
Comprehensive ethnographies that record truly extensive data about a group are becoming unfortunately rare. Many articles and books seem driven by the author's desire to advance a theory, rather than by interest in human beings. This book should be a shining example for all of us.

The only drawback to this book is the use of Venezuelan Spanish. Many localisms will be strange to those who know only "Academy" Spanish. Context and photographs make most of the usages clear, but cambur drove me to the dictionary (it is a type of banana).

Last and best: the photographs in this book are nothing short of incredible. This is one of the most beautiful ethnographies ever published. Even more important is the value of the photographs for documenting every aspect of Jotï life, from hunting to schools, from fishing to festivals, from wild landscapes to settled villages. The book is worth finding even for those who do not read Spanish, for the photographs alone. 